\title{
Dental anxiety and the status of first permanent molars in 11 and 15 years old children
}

\author{
Milka Kapuran', Svetlana Janković2, Bojana Davidović ${ }^{2}$, Jelena Lečić \\ 'Primary Health Care Center Rogatica, Rogatica, Republika Srpska, Bosnia and Hercegovina; \\ ${ }^{2}$ University of East Sarajevo, Faculty of Medicine, Section of Dentistry, Department of Preventive Dentistry and \\ Orthodontics, Foča, Republika Srpska, Bosnia and Herzegovina
}

\begin{abstract}
SUMMARY
Introduction Fear of dental procedures is one of the main reasons for oral health neglect. The first permanent molars are functionally very important. Dental anxiety may compromise their health as well as the health of all other teeth. The aim of the study was to determine dental anxiety level and the status of first permanent molars in healthy school aged children.

Methods This study included 105 students, 11 and 15 years of age, from two elementary schools in Foca (Bosnia and Herzegovina). Dental Anxiety Scale (DAS), questionnaire was used to determine the level of dental fear in patients. The status of first permanent molars was recorded using Klein-Palmer DMFT (decayed, missing, filling teeth) system. The number of healthy first permanent molars (with or without sealant) was registered as well.

Results More than one third of respondents involved in this study (33.3\%), suffered from severe dental anxiety (DAS $=13-20$ points). Statistically significant difference in answers to questions was not observed between respondents of different age but higher level of the fear was registered in girls compared to boys $(p<0.05)$. Less than $50 \%$ of all examined first permanent molars were healthy and sealed fissures were recorded in $9.4 \%$ of them. The percentage of decayed molars was about $11 \%$, $7 \%$ extracted and $35 \%$ filled.

Conclusion Application of prophylactic measures is beneficial for dental health preservation. They are pain free and can be used to minimize fear by establishing dentist-patient relationship based on confidence.
\end{abstract}

Keywords: dental anxiety; the fear; the first permanent molar; oral health; decay

\section{INTRODUCTION}

In the era of modern dentistry when dental procedures are completely painless, a fear of dentist still exist in children and adults. This fear is one of the main reasons for oral health care neglect. Under the concept "fear of dentist," it is possible to distinguish dental anxiety, dental fear and dental phobia [1].

Dental anxiety is the mildest form of fear of dentist, and is characterized by patients' excitation and a sense of control loss [2]. Dental fear presents an active response to a known danger, that is object or situation, and occurs in people who have already had unpleasant dental experience and expect that this will inevitably happen again [3]. Dental phobia is the most intensive fear of dentist and presents narrowly defined diagnosis made by psychologists and psychiatrists. This mental disorder is characterized by a pronounced fear or avoidance of a particular object or situation that significantly interfere with the function or causes considerable emotional stress of a patient $[3,4]$. Fear of dental procedures can cause serious health problems, as avoiding dental visits may lead to complications of diseased oral tissues [5]. Fear of dental intervention is in high fourth rank in relation to other situations that cause fear. It can be the cause of so-called vicious circle, when dental fear leads to dental visits delay, which may further increase present difficulties and already present fear [6]. Otherwise, fear is a subjective category that is not comarable between the two persons. Clinically, it is manifested by dilated pupils, dry mouth, rapid breathing, tachycardia, excessive sweating, cold hands. All of these clinical signs are result of increased adrenocortical hormone - adrenaline, and clinical picture is dominated by the effect of the sympathetic nervous system [7].

The first permanent molars are, in most cases, the first permanent teeth that erupt in children [8]. These functionally important teeth in humans are significant indicators of permanent teeth caries presence as well as preventive prophylactic and therapeutic measures applied [9]. Therefore, the status of first permanent molar health to some extent may be an indirect indicator of dental fear in patients.

The aim of the study was to determine dental anxiety level and the status of first permanent molars in healthy school aged children. 


\section{MATERIALS AND METHODS}

The study involved pupils from two elementary schools in Foca (Bosnia and Herzegovina), aged 11 and 15 years. Parents of the respondents were informed in details about the nature and the course of the study and gave consent for the inclusion of their children in the study. This study was conducted according to the recommendations of the Helsinki Declaration and the principles of Good Clinical Practice.

Dental Anxiety Scale (DAS) questionnaire was used for to assess the level of fear in patients. The questionnaire was prepared according to the Corah's Dental Anxiety Scale that was published in 1969 and considered to be valuable and reliable indicator in clinical trials [10]. The questionnaire consists of four questions about the situations related to dental treatment and every question has 5 answers. The answers were scored according to the fivepoint Likert scale $(\mathrm{a}=1, \mathrm{~b}=2, \mathrm{c}=3, \mathrm{~d}=4$ and $\mathrm{e}=5)$, and the level of anxiety was calculated from the sum of points:

- Between 4-8 - no anxiety

- Between 9-12 - moderate anxiety

- Between 13-14 - high anxiety

- Beetween 15-20 - severe anxiety

Clinical examination was performed in all subjects. Dental examinations were performed in schools using standard dental instruments, dental explorer and mirror. The status of first permanent molars was recorded using Klein-Palmer DMFT (decayed, missing, filling teeth) system [11]. Also, the number of healthy first permanent molars (with or without sealant) was recorded, while other permanent teeth were not taken into consideration.

Data were presented by standard methods of descriptive statistics (percentage, mean $(\mathrm{X})$, standard deviation $(\mathrm{SD})$ ). Differences between groups were tested using Mann-Whitney U-test and t-test. SPSS 11.5 for Windows Statistical Program was used for data analysis.

\section{RESULTS}

The study involved 105 subjects: 52 girls (49.4\%) and 53 boys and (50.5\%). The average age of female respondents was $13 \pm 1.4$ and $13 \pm 1.8$ for male subjects. The distribution of subjects by gender, age and the frequency of dental visits is presented in Table 1.

More than one third of involved respondents (33.3\%, DAS $=13-20$ points) had high and severe level of dental anxiety. In almost $40 \%$ of respondents fear of dental procedures was not found (DAS $=4-8$ points). No statistically significant differences in answers to questions were observed between respondents of different age but higher value of the fear was present in girls $(21,9 \%$, DAS $=13-20$ points) than boys (11,4\%, DAS $=13-20$ points). This difference was statistically significant $(\mathrm{p}<0.05)$. Table 2 shows detailed relationship between anxiety of dental procedures and behavior of subjects given by the Corah's Dental Anxiety Scale questionnaire.

More than $40 \%$ of children go to regular dental checkups several times a year. On the other hand, about $5 \%$ of children visited a dentist only once in several years.
Table 1. Distribution of patients by gender, age and frequency of dental visits

Tabela 1. Raspodela ispitanika prema polu, uzrastu, kao i učestalosti poseta stomatologu

\begin{tabular}{|l|c|c|}
\hline & $\mathbf{n}$ & (\%) \\
\hline $\begin{array}{l}\text { Gender } \\
\text { Pol pacijenta }\end{array}$ & & \\
\hline Male/Muški & 53 & $(50.5)$ \\
\hline Female/Ženski & 52 & $(49.5)$ \\
\hline Total/Ukupno & 105 & $(100.0)$ \\
\hline $\begin{array}{l}\text { Patient's age } \\
\text { Uzrast pacijenta }\end{array}$ & & \\
\hline 11 years / godina & 51 & $(48.5)$ \\
\hline 15 years / godina & 54 & $(51.4)$ \\
\hline Total / Ukupno & 105 & $(100.0)$ \\
\hline $\begin{array}{l}\text { The frequency of dental visits } \\
\text { Učestalost poseta stomatologu }\end{array}$ & & \\
\hline Once a year / Jedanput godišnje & 23 & $(21.9)$ \\
\hline Twice a year / Dvaput godišnje & 32 & $(30.4)$ \\
\hline Several times a year / Nekoliko puta godišnje & 45 & $(42.8)$ \\
\hline Once in several years / Jednom u nekoliko godina & 5 & $(4.8)$ \\
\hline Total/Ukupno & 105 & $(100.0)$ \\
\hline $\begin{array}{l}\text { Last visit to the dentist for check-up } \\
\text { Poslednja poseta stomatologu zbog } \\
\text { kontrolnog pregleda }\end{array}$ & 27 & $(25.7)$ \\
\hline In the last 30 days / U poslednjih mesec dana & 34 & $(41.2)$ \\
\hline In the last 6 months / U poslednjih šest meseci & & $(28.5)$ \\
\hline U poslednjih godinu dana / In a last year & 105 & $(100.0)$ \\
\hline In the last several years / U poslednjih nekoliko godina & 4 & \\
\hline Never/Nikad & & \\
\hline Total/Ukupno & & \\
\hline
\end{tabular}

Table 2. Dental anxiety in relation to sex and age at Corah's total score

Tabela 2. Dentalna anksioznost u odnosu na pol i uzrast po Corah's Dental Anxiety Scale

\begin{tabular}{|c|c|c|c|c|c|}
\hline \multirow{2}{*}{$\begin{array}{l}\text { (DAS)/ } \\
\text { Norman } \\
\text { Corah's } \\
\text { scale }\end{array}$} & \multicolumn{2}{|c|}{$\begin{array}{c}\text { Child age } \\
\text { Uzrast }\end{array}$} & \multicolumn{2}{|c|}{$\begin{array}{c}\text { Gender } \\
\text { Pol }\end{array}$} & \multirow{2}{*}{$\begin{array}{c}\text { Total } \\
\text { Ukupno } \\
\text { n (\%) }\end{array}$} \\
\hline & 11 n (\%) & 15 n (\%) & $\begin{array}{c}\text { Male } \\
\text { Muški } \\
\text { n (\%) }\end{array}$ & $\begin{array}{c}\text { Female } \\
\text { Ženski } \\
\text { n (\%) }\end{array}$ & \\
\hline $\begin{array}{l}4-8 \\
\text { No anxiety } \\
\text { Nema strah }\end{array}$ & $20(19.0)$ & $21(20.0)$ & $24(22.8)$ & $17(16.2)$ & $41(39.0)$ \\
\hline $\begin{array}{l}9-12 \\
\text { Moderate } \\
\text { anxiety } \\
\text { Umereni } \\
\text { strah }\end{array}$ & $13(12.4)$ & $16(15.2)$ & $17(16.2)$ & $12(11.4)$ & $29(27.6)$ \\
\hline $\begin{array}{l}13-14 \\
\text { High anxiety } \\
\text { Izražen strah }\end{array}$ & $12(11.4)$ & $10(9.5)$ & $8(7.6)^{*}$ & $14(13.3)^{*}$ & $22(20.9)$ \\
\hline $\begin{array}{l}15-20 \\
\text { Severe } \\
\text { anxiety } \\
\text { Veoma } \\
\text { izražen strah }\end{array}$ & $6(5.7)$ & $7(6.7)$ & $4(3.8)^{*}$ & $9(8.6)^{*}$ & $13(12.4)$ \\
\hline $\begin{array}{l}X^{2} \\
P \text { value } \\
P \text { vrednost }\end{array}$ & & & & 0.05 & \\
\hline
\end{tabular}

However, children who visited dentist once a year or less experienced high degree of dental anxiety as confirmed by statistically significant difference $(\mathrm{p}<0.05)$ compared to the children without fear who practice regular dental visits. 


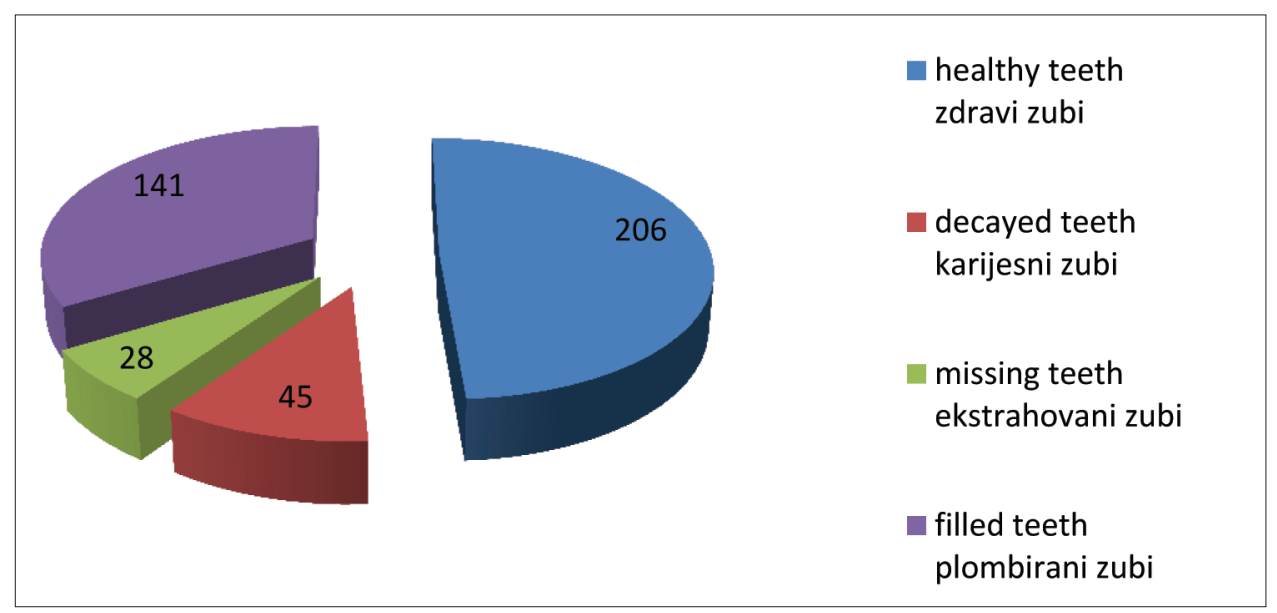

Figure 1. Total number of healthy, decayed, missing and filled teeth

Slika 1. Ukupan broj zdravih, karioznih, ekstrahovanih i plombiranih zuba

Less than $50 \%$ of the first permanent molars were completely healthy in both age groups. Percentage of sealed fissures in healty first permanent molars was $9.4 \%$, the percentage of decayed molars was almost $11 \%$, extracted almost 7\%, while the percentage of filled was around $35 \%$ (Graph 1). 34 children had all four first permanent molars completely healthy, while in 4 children all four molars have already been extracted. The most frequently extracted tooth was lower right first molar. Eleven years old children had more healthy first permanent molars compared to fifteen years olds, however, the difference between the groups was not statistically significant. Also, boys had higher number of healthy molars, as well as higher percentage of filled teeth compared to girls, but the difference was not statistically significant.

\section{DISCUSSION}

The results of the current study indicate the presence of high level of dental anxiety and high prevalence of first permanent molars decay. Therefore, the fear of dental procedures is an important problem in everyday practice, not only in pediatric dentistry but in other fields of dentistry as well. Studies that have investigated this issue indicate that dental anxiety is present at all ages and is not related to gender [12-15].

No anxiety was found in $39 \%$ of subjects of this study, moderate anxiety was identified in $27.6 \%$ of subjects while high and severe anxiety were registered in more than one third of subjects (33.2\%). These results are comparable to similar studies. The study done by Alak at al. (2012) indicated $34 \%$ of children, 11 to 15 years of age, had high and severe dental anxiety while $32.4 \%$ children showed no fear [12]. For adult subjects, studies showed high and severe dental anxiety present in almost $30 \%$ of participants aged $18-82$ years while $34.6 \%$ of subjects showed no dental anxiety [14].

Dental fear negatively impacts both patients and dentists. It can be avoided or minimized by establishing good dentist-patient relationship based on confidence or by implementation of good introduction about upcoming dental intervention [16]. Also, in the age of information systems, patient frequently firstly consults newspapers and Internet what could also result in additional negative outcomes due to incorrect information [17]. It is therefore necessary for a dentist to provide proper information, attract sympathy of patients and gain their trust.

Respondents included in the current study were eleven and fifteen years of age, a period of intense shifts of deciduous and permanent teeth, as well as completion of permanent dentition. Dental anxiety was equaly present among the respondents. The frequency of dental visits was significantly lower in anxious patients. It has been proven that children who go to the dentist once a year or less, have higher dental anxiety level than those who visit dentists twice a year. The results also showed higher prevalence of dental anxiety in girls and that is in accordance with other studies that also reported women experience greater fear of dental procedures $[12,18]$. This can be explained by the fact that females are more prone to having higher levels of neuroticism as well, and anxiety is positively associated with neuroticism [19].

Time spent in the waiting room proportionally increases the level of anxiety. Despite relatively frequent occurrence of dental anxiety, dentists often do not have enough understanding and knowledge about the psychological approach to such persons [17]. However, due to increasingly serious legislation treatment of this phenomenon, and the threat of lawsuits, it is necessary to develop special techniques of communication [17]. According to Hmudu (2009) there are four different fear triggers that patients respond to differently, and can be displayed as a "Rule 4 S" [20]:

- Sights - visual experience (needles, drills)

- Sounds - sounds (slow speed handpiece, high speed handpiece)

- Sensations - feelings (vibrations)

- Smells - odors (different dental materials)

The results of our study indicated that more than half of all examined first permanent molars had some of DMFT components. Percentage of teeth with sealed fissures $(9.4 \%)$ was relatively small, and that is one of the fear parameters as fissures sealing process is fast, easy, completely painless and therefore suitable for massive ap- 
plication and fear elimination. Our study also indicated the prevalence of first permanent molars decay increased with age of respondents as previously indicated by other authors $[21,22]$. Also, due to strong prevention programs, there has been a constant decline in permanent teeth decay prevalence in developed countries [9]. However, in our region, the percentage of extracted first permanent molars continuously increases with the age of respondents. Out of the total number of inspected teeth in this study, about $7 \%$ of them have already been extracted, which is devastating fact as the first permanent molar has very important functional significance [8] and its extraction may have many negative consequences [22]. The prevalence of tooth decay in all ages was higher in girls, but without significant difference in comparison to boys.

Some studies showed that socio-economic status and education level might impact the prevalence of dental anxiety in the population $[6,23]$. The highest levels of anxiety are registered in adolescents, which are mainly resulted by their own bad childhood experiences or negative experiences of parents or friends [17]. Studies have shown that the average age of about 40 years, both for women and men, is when fear reduction begins. This can be explained by increased tolerance, due to more frequent and prolonged exposure to stressful situations as well as life experiences that shape behavioral characteristics of individuals [18]. Anxious patients require special attention, and DAS questionnaire can be used in dental practise as guidance in decision-making whether a dental treatment requires specific techniques such as sedation or even general anesthesia.

\section{CONCLUSION}

Dental anxiety is important reason for dental visits avoidance. It can certainly contribute to poor oral health as well as development of dental complications. Almost every third child from this study experienced noticeable dental anxiety. School age life period is most critical but also the most important for application of preventive and prophylactic measures and procedures that aim oral health preservation. The most efficient prophylactic measure for reduction of tooth decay is fissure sealant aplication.

Fissure sealant aplication is completely pain free procedure that can be used as a way to release or reduce fear in patients. Dental anxiety awareness of dentists is also essential for good communication establishment and proper approach to patient in everyday practice.

\section{REFERENCES}

1. Medojević MJ, Nešković J, Medojević A. Dental Anxiety: Etiology and Treatment Options. Serbian Dental Journal. 2015; 62(4):17483. [DOI: 10.1515/sdj-2015-0018]

2. Moola S, Pearson A, Hagger C. Effectiveness of music interventions on dental anxiety in paediatric and adult patients: a systematic review. JBL Library System Rev. 2011; 9:588-630. [DOI: 10.11124/ jbisrir-2011-136]
3. Armfield J M, Heaton LJ. Management of fear and anxiety in dental clinic: a review. Aust Dent J. 2013; 58(4):390-407. [DOI: 10.1111/ adj.12118] [PMID: 24320894]

4. American Psychiatric Association. Diagnostic and Statistical Manual and Mental Disorders. 4th ed. Washington, DS: American Psychiatric Association; 2000.

5. The Joanna Briggs Institute. Music interventions for dental anxiety in pediatric and adult patients. Best Practice. 2011; 15:1-4.

6. Đorđevič F, Stanišić J, Đorđević A, Vlahović Z, Mladenović R. Bol i oprevdanost straha od stomatološke intervencije. Praxis Medica. 2015; 44(2):27-30. [DOI: 10.5937/pramed1502027D]

7. Milanović J, Marković D. Strah od stomtoloških intervencija. Stomatolog. 2014; 20: (3-4):12-8.

8. Halicioglu K, Toptas O, Akkas I, Celikoglu M. Permanent first molar extraction in adolescents and young adults and its effect on the development of third molar. Clin Oral Investig. 2014; 18(5):148994. [DOI: 10.1007/s00784-013-1121-1]

9. Legović I, Kotarac-Knezević A, Cabov T, Brumini G, Sasso A, Kovac $Z$, et al. Health condition of first permanent molars in year 1977 and 2007 in children in Istria (Croatia). Collegium antropologicum. 2010; 34(3):1035-38. [PMID: 20977099]

10. Corah NL. Development of a dental anxiety scale. J Dent Res. 1969; 48(4):596. [DOI: 10.1177/00220345690480041801] [PMID: 5256508]

11. World Health Organization. Oral Health Surveys. Basic Methods. 4th edn. Geneva: World Health Organization; 1997.

12. Alaki S, Alotaibi A, Almabadi E, Alanquri E. Dental anxiety in middle school children and their caregivers: Prevalence and severity. J Dent Oral Hyg. 2012; 4(1):6-11. [DOl: 10.5897/JDOH11.019]

13. Armfield JM, Slade GD, Spencer AJ. Dental fear and adult oral health in Australia. Community Dent Oral Epidemiol. 2009; 37(3):220-30. [DOI: 10.1111/j.1600-0528.2009.00468.x.] [PMID: 19508270]

14. Kirova DG, Atanasov DT, Lalabonova CK, Janevska S. Dental anxiety in adults in Bulgaria. Folia Med (Plovdiv). 2010; 52(2):49-56. [PMID: 20836397]

15. Sghaireen MG, Zwiri AM, Alzoubi IA, Qodceih SM, Al-Omiri MK. Anxiety due to Dental Treatment and Procedures among University Students and Its Correlation with Their Gender and Field of Study. Int J Dent. 2013; 2013:647436. [DOl: 10.1155/2013/647436].

16. De Jongh A, Adair P, Meijerink-Amderson M. Clinical menagment of dental anxiety: what works on whom? Int Dent J. 2005; 55(2):7380. [DOI: 10.1111/j.1875-595X.2005.tb00037.x] [PMID: 15880961]

17. Perković I, Perić M, Knežević-Romić M, Kremek Jukić S. Razina anksioznosti i percepcija bola endodontskih pacijanata. Acta Stomatologica Croat. 2014; 48(4):258-67. [DOI: 10.15644/asc48/4/3]

18. Locker D, Liddell A, Burman D. Dental fear and anxiety in an older adult population. Community Dent Oral Epidemiol. 1991; 19(2):120-4. [PMID: 2049919]

19. Stecher T. Well-being in an academic environ ment. Med Educ. 2004; 38(5):465-78. [DOI: 10.1046/j.1365-2929.2004.01812.x] [PMID:15107080]

20. Hmud R, Walsh LJ. Dental anxiety: Causes, complications and management approaches. J Minim Interv Dent. 2009; 2(1):67-78.

21. Al-Samadani KH, Ahmad MS. Prevalence of First Permanent Molar Ceris in and Its Relationship to the dental Knowledge of 9-12 Year Olds from Jeddah, Kingdom of Saudi Arabi. ISRN Dentistry. 2012; 2012:391068:1-7. [DOI: 10.5402/2012/391068] [PMID: 22461990]

22. Stojković $B$, Apostolović $M$, Igić $M$, Tričković-Janjić $O$, Kostadinović Lj, Šurdilović D. i dr. Uporedna analiza prevalence karijesa prvih stalnih molara kod dece mlađeg i starijeg školskog uzrasta. Acta Stomatologica Naissi. 2012; 28(66):1180-90. [DOI: 10.5937/ asn1266180S]

23. Bushara M, Ehtesam K, Muslim K. Dental anxiety scale in endodontia patients. JKCD. 2011; 1(2):66-70. 


\title{
Strah od stomatološkog lečenja i zdravlje prvih stalnih molara kod dece uzrasta 11 i 15 godina
}

\author{
Milka Kapuran', Svjetlana Janković², Bojana Davidović2, Jelena Lečić \\ 'Dom zdravlja Rogatica, Rogatica, Republika Srpska, Bosna i Hercegovovina; \\ ${ }^{2}$ Univerzitet u Istočnom Sarajevu, Medicinski fakultet, Odsek Stomatologija, Katedra za dečju i preventivnu stomatologiju sa \\ ortodoncijom, Foča, Republika Srpska, Bosna i Hercegovina
}

\begin{abstract}
KRATAK SADRŽAJ
Uvod Strah od stomatoloških intervencija predstavlja jedan od osnovnih razloga zbog kojeg se zanemaruje briga o oralnom zdravlju. Prvi stalni molari su funkcionalno veoma značajni zubi, a dentalna anksioznost može doprineti da se ugrozi zdravlje kako ovih tako i svih zuba.

Cilj ovog rada je bio da se utvrdi nivo dentalne anksioznosti i stanje zdravlja prvih stalnih molara kod dece školskog uzrasta.

Metode rada Istrživanjem je obuhvaćeno 105 učenika iz dve osnovne škole u Foči (Bosna i Hercegovina), uzrasta 11 i 15 godina. Za procenu nivoa straha kod pacijenata korišćen je upitnik Dental Anxiety Scale (DAS). Stanje zdravlja prvih stalnih molara ocenjeno je pomoću Klajn-Palmerovog KEP (karijes, ekstrakcija, plomba) sistema, a registrovani su i zdravi i zaliveni prvi stalni molari. Rezultati Više od trećine ispitanika koji su uključeni u studiju (33,3\%) pati od visoke i veoma visoke stomatološke anksioznosti (DAS = 13-20 poena). Nema statistički značajne razlike u odgovorima na pitanja vezanim za uzrast ispitanika, ali su devojčice osećale veći strah u poređenju sa dečacima $(\mathrm{p}<0,05)$. Manje od $50 \%$ svih pregledanih prvih stalnih molara je bilo potpuno zdravo, a zalivene fisure su registrovane kod 9,4\% pregledanih molara. Procenat karioznih molara u ovom istraživanju je bio oko 11\%, ekstrahovanih skoro $7 \%$, dok je oko $35 \%$ bilo plombiranih.

Zaključak Primena profilaktičkih mera predstavlja dobar način zaštite zdravlja zuba. Njihova primena je potpuno bezbolna i može poslužiti kao način za oslobađanje straha od stomatoloških intervencija i sticanje odnosa poverenja između lekara i pacijenata. Ključne reči: dentalna anksioznost; prvi stalni molar; zdravlje; karijes
\end{abstract}

\section{UVOD}

U eri savremene stomatologije, kada su stomatološki zahvati potpuno bezbolni, i dalje je kod dece, ali i odraslih osoba, prisutan strah od stomatologa. Upravo taj strah predstavlja jedan od osnovnih razloga zbog kojeg se zanemaruje briga o oralnom zdravlju. Pod pojmom strah od stomatologa moguće je razlikovati dentalnu anksioznost, dentalni strah i dentalnu fobiju [1].

Dentalna anksioznost je najblaži oblik straha od stomatologa, a karakteriše je uzbuđenje pacijenata i osećaj gubitka kontrole [2]. Dentalni strah predstavlja aktivan odgovor na poznatu opasnost, tj. objekat ili situaciju, jer se javlja kod osoba koje su već imale loša stomatološka iskustva i očekuju da se to neminovno ponovi [3]. Dentalna fobija je najintenzivniji oblik straha od stomatologa i predstavlja usku definisanu dijagnozu od strane odgovarajućih psihologa i psihijatra. Ovaj mentalni poremećaj karakteriše izražen strah ili izbegavanje određenog objekta ili situacije koja značajno ometa funkciju pacijenta ili uzrokuje znatan emotivni stres [3,4]. Strah od stomatoloških zahvata može biti uzrok teških zdravstvenih problema, jer izbegavanje poseta stomatologu neminovno vodi do komplikacija u terapiji obolelih oralnih tkiva [5]. Strah od stomatološke intervencije je na visokom četvrtom mestu po rangu u odnosu na ostale situacije koje izazivaju strah. Može biti uzrok takozvanog začaranog kruga prema kome prisutna odontofobija dovodi do odlaganja odlaska u stomatološku ordinaciju, što povećava prisutne tegobe, a što propratno povećava već prisutni novi strah [6]. Inače, strah je subjektivna kategorija koja ne podleže komparaciji između dve osobe. Klinički se manifestuje proširenim zenicama, suvoćom usana, ubrzanim disanjem, tahikardijom, pojačanim znojenjem, hladnim rukama. Svi ovi klinički znaci su posledica pojačanog lučenja hormona kore nadbubrežne žlezde - adrenalina, tako da kliničkom slikom dominira efekat simpatičkog nervnog sistema [7].
Prvi stalni molari su najćešće prvi stalni zubi koji niču u ustima deteta [8]. Ovi funkcionalno značajni zubi čoveka predstavljaju i veoma značajne indikatore za pojavu karijesa stalnih zuba, odnosno značajne pokazatelje uspešnosti primene preventivno-profilaktičkih i terapijskih mera [9]. Samim tim i stanje zdravlja prvog stalnog molara u određenoj meri može biti i indirektni pokazatelj prisutnog straha od stomatološkog lečenja kod pacijenata.

Cilj ovog rada je bio da se utvrdi nivo dentalne anksioznosti i stanje zdravlja prvih stalnih molara kod dece školskog uzrasta.

\section{METODE}

Istraživanjem su obuhvaćeni učenici dve osnovne škole u Foči (Bosna i Hercegovina), uzrasta 11 i 15 godina. Roditelji ispitanika su bili detaljno informisani o prirodi i toku istraživanja i dali su svoj pristanak za uključivanje dece u studiju. Istraživanje je obavljeno prema preporukama Helsinške deklaracije i principima Dobre kliničke prakse.

Za procenu nivoa straha kod pacijenata korišćen je upitnik Dental Anxiety Scale (DAS). Upitnik je bio pripremljen prema uzoru na Corah's Dental Anxiety Scale, koji je objavljen 1969. godine i koji se smatra vrednim i pouzdanim pokazateljem u kliničkim istraživanjima [10]. Upitnik se sastoji od četiri pitanja koja se odnose na situacije vezane za stomatološki tretman, a svako pitanje ima pet odgovora. Odgovori su bodovani prema petostepenoj Likertovoj skali $(\mathrm{a}=1, \mathrm{~b}=2, \mathrm{c}=3, \mathrm{~d}=4 \mathrm{i} \mathrm{e}=5)$, a stepen anksioznosti je izračunavan na osnovu zbira bodova:

- 4-8 - nema anksioznosti

- 9-12 - postoji umerena anksioznost

- 13-14 - postoji visoki stepen anksioznosti

- 15-20 - postoji veoma visok stepen anksioznosti 
Kod svih ispitanika je urađen klinički stomatološki pregled. Pregledi su obavljeni u školama uz pomoć standardnih stomatoloških instrumenata, sonde i ogledalca. Stanje zdravlja prvih stalnih molara registrovano je upotrebom Klajn-Palmerovog KEP (karijes, ekstrakcija, plomba) sistema [11]. Takođe su registrovani i zdravi prvi stalni molari (sa zalivačima i bez njih), dok ostali stalni zubi nisu uzimani u obzir.

Podaci su prikazani standardnim metodama deskriptivne statistike (procentualna zastupljenost, srednja vrednost (X), standardna devijacija (SD)). Za testiranje razlika između dve grupe korišćen je Mann-Whitney U-test i t-test. Za analizu podataka korišćen je SPSS 11.5 za Windows, a dobijeni rezultati prikazani su tabelarno i grafički.

\section{REZULTATI}

U istraživanju je učestovalo ukupno 105 ispitnika: 52 devojčice $(49,4 \%)$ i 53 dečaka (50,5\%). Prosečna starost ispitanika ženskog pola je $13 \pm 1,4$, a ispitanika muškog pola $13 \pm 1,8$. Raspodela ispitanika prema polu, uzrastu, kao i učestalosti poseta stomatologu prikazana je u Tabeli 1 .

Rezultati ovog istraživanja pokazuju da više od trećine ispitanika koji su uključeni u studiju (33,3\%, DAS = 13-20 poena) ima visok stepen i veoma visok stepen stomatološke anksioznosti. Kod skoro $40 \%$ ispitanika je utvrđeno da ne postoji strah od stomatoloških intervencija (DAS $=4-8$ poena). Nije bilo statistički značajne razlike u odgovorima na pitanja između testiranih uzrasta ispitanika, ali su devojčice osećale veći strah $(21,9 \%$, DAS $=13-20$ poena $)$ u poređenju sa dečacima $(11,4 \%$, DAS $=13-20$ poena). Ova razlika je bila statistički značajna (p $<0,05)$. Tabela 2 pokazuje detaljniju povezanost između straha od stomatoloških intervencija i ponašanja ispitanika koja je data u Korahovoj skali, tj. upitniku.

Rezultati ukazuju da više od $40 \%$ dece odlazi na redovne stomatološke preglede nekoliko puta godišnje. Međutim, treba napomenuti da je u ovom uzrastu oko 5\% dece posetilo stomatologa samo jednom tokom nekoliko godina. Analiza rezultata je takođe pokazala da deca koja kod stomatologa odlaze jednom godišnje ili ređe imaju visok stepen anksioznosti, što je potvrdila statistički značajna razlika u odnosu na decu koja se ne plaše $\mathrm{i}$ idu na redovne kontrole $(\mathrm{p}<0,05)$.

Rezultati pokazuju da je nešto manje od $50 \%$ prvih stalnih molara bilo potpuno zdravo u oba uzrasta. Na zdravim molarima procenat zalivenih fisura je iznosio 9,4, procenat karioznih molara skoro 11, ekstrahovanih oko 7, dok je procenat plombiranih bio oko 35 (Grafikon 1). U ovom istraživanju 34 dece je imalo sva četiri prva stalna molara potpuno zdrava, dok su kod četiri deteta sva četiri molara bila ekstrahovana. Najčešće vađeni zub je bio donji desni prvi molar. Jedanaestogodišnjaci su imali više zdravih prvih stalnih molara u odnosu na petnaestogodišnjake, ali razlika između ispitivanih grupa nije bila statistički značajna. Pokazalo se da dečaci imaju zdravije molare, kao i veći procenat plombiranih zuba u poređenju sa devojčicama, ali bez statističke značajnosti.

\section{DISKUSIJA}

Sprovedeno istraživanje, kojim su bila obuhvaćena deca uzrasta 11 i 15 godina na teritoriji opštine Foča, ukazuje na povećan stepen anksioznosti, kao i visoku prevalencu karijesa prvih stalnih molara. Zato je strah od stomatoloških intervencija važan problem u svakodnevnoj praksi, ne samo u dečjoj stomatologiji već u svim granama stomatologije. Studije koje su ispitivale ovu tematiku ukazuju da je dentalna anksioznost prisutna u svim uzrastima i da je nezavisna od pola [12-15].

$\mathrm{U}$ ovom istraživanju odsustvo anksioznosti ustanovljeno je kod 39\% ispitanika, umerena anksioznost kod 27,6\% ispitanika, dok je visok i veoma visok stepen anksioznosti bio prisutan kod više od trećine ispitanika (33,2\%). Ovi podaci su uporedivi sa rezultatima sličnih studija. Tako Alaki i sar. 2012. ukazuju da 34\% dece uzrasta 11-15 godina ima visoku i veoma visoku dentalnu anksioznost, dok kod 32,4\% dece nije bio prisutan strah [12]. Kada su odrasli u pitanju, studije ukazuju na visoku i veoma visoku dentalnu anksioznost u uzrastu 18-82 godine kod skoro $30 \%$ ispitanika, dok kod 34,6\% ispitanika ona nije uočena [14].

Strah negativno utiče kako na pacijenta tako i na stomatologa. Može se izbeći ili umanjiti uspostavljanjem poverenja između stomatologa i pacijenta, odnosno dobrim informisanjem pacijenta o predstojećoj stomatološkoj intervenciji [16]. Dodatni problem je činjenica što u doba informativnih sistema pacijent obično prvo konsultuje časopise i internet, što takođe može imati negativne posledice usled sticanja mogućih pogrešnih informacija [17].Zbog toga je potrebno da informacije pruži sam stomatolog, koji uz to može zadobiti i simpatije pacijenta, odnosno steći njegovo poverenje.

Ispitanici uključeni u ovu studiju su uzrasta od 11 i 15 godina, a to je period intenzivne smene mlečnih i stalnih zuba, ali i kompletiranja stalne denticije. Dentalna anksioznost bila je podjednaka i nije bilo statistički značajne razlike između ispitanika. Učestalost odlaska stomatologu bitno je manja kod anksioznih pacijenata. Dokazano je da deca koja odlaze kod stomatologa jednom godišnje i ređe imaju veći stepen anksioznosti u odnosu na onu koji ga posećuju dva i više puta u toku godine. Rezultati takođe ukazuju da je dentalna anksioznost prisutnija kod devojčica, što je u skladu sa rezultatima drugih studija koje ukazuju da pacijenti ženskog pola imaju veći strah od stomatoloških intervencija $[12,18]$. Ova veza može biti objašnjena činjenicom da su žene sklonije i većem stepenu neuroticizma, a anksioznost je pozitivno povezana sa neuroticizmom [19].

Vreme provedeno u čekaonici proporcionalno povećava nivo straha. Uprkos relativno čestoj pojavi dentalne anksioznosti, iznenađuje činjenica da stomatolozi nemaju uvek dovoljno razumevanja, ali ni znanja o psihološkom pristupu takvim osobama [17]. Međutim, i zbog zakonske regulative koja počinje ozbiljnije tretirati ove pojave, te opasnosti od tužbi, potrebno je razviti posebne tehnike komunikacije [17]. Prema Hmudu, postoje različiti okidači straha na koje pacijenti različito reaguju, a mogu se prikazati kao pravilo $4 S$ (na engleskom jeziku) [20]:

- sights - vizuelni doživljaj (igle, boreri)

- sounds - zvukovi (mikromotor, turbina)

- sensations - osećaji (vibracije)

- smells - mirisi (različiti stomatološki materijali)

Rezultati ovog istraživnja ukazuju da više od pola svih pregledanih prvih stalnih molara ima neku od komponenti KEP-a. Procentat zalivenih fisura $(9,4 \%)$ relativno je mali, što je takođe jedan od parametara straha. Naime, postupak zalivanja fisura je brz, jednostavan i potpuno bezbolan i zbog toga vrlo pogodan za masovniju primenu i eliminaciju straha. Rezultati dobijeni ovim istraživanjem pokazuju da prevalenca karijesa prvih 
stalnih molara raste sa uzrastom ispitanika, na šta su i ranije ukazali drugi autori [21,22].S druge strane, zahvaljujući jakim preventivnim programima, u zemljama razvijenog sveta beleži se konstantno opadanje prevalence karijesa stalnih zuba [9]. Međutim, u našoj regiji procenat ekstrahovanih prvih stalnih molara se kontinuirano povećava sa uzrastom ispitanika. Od ukupnog broja pregledanih zuba u ovoj studiji, oko 7\% je već bilo izvađeno. Inače, prvi stalni molar ima izuzetno važan funkcionalni značaj [8], tako da ekstrakcije ovog zuba mogu imati mnogobrojne negativne posledice [22]. Prevalenca karijesa ispitivanih zuba u svim uzrastima ispitanika bila je veća kod devojčica, ali bez statističke značajnosti u odnosu na dečake.

Pojedine studije su pokazale da socioekonomski status i nivo edukacije stanovništva može imati uticaja na stepen prisustva dentalnog straha u populaciji $[6,23]$. Najveći nivo anksioznosti imaju adolescenti, što je uglavnom rezultat vlastitih loših iskustava u detinjstvu ili negativnog iskustva roditelja ili prijatelja [17]. Istraživanja su pokazala da je prosečna dob, i za žene i za muškarce, u kojoj počinje redukcija straha oko 40 godina. To se može objasniti povećanom tolerancijom zbog sve češćeg i dužeg izlaganja stresnim situacijama, te životnim iskustvom koje oblikuje bihevioralne karakteristike pojedinca [18]. Anksiozni pacijenti zahtevaju posebnu pažnju, a DAS upitnik može poslužiti stomatolozima u lakšem odlučivanju o tome da li će pacijentima predložiti posebne tehnike kao što su sedacija ili u određenim slučajevima opšta anestezija.

\section{ZAKLJUČAK}

Dentalna anksioznost i danas predstavlja veoma važan razlog izbegavanja odlaska kod stomatologa. To svakako može doprineti lošem oralnom zdravlju, kao i razvoju komplikacija dentalnih oboljenja, što je veoma zabrinjavajuće, s obzirom na činjenicu da skoro svako treće dete iz ove studije ima izraženu dentalnu anksioznost. Period školskog uzrasta dece je najkritičniji, ali ujedno i najznačajniji za primenu preventivno-profilaktičkih mera i postupaka koje imaju za cilj očuvanje zdravlja kako tvrdih tako i svih oralnih tkiva. Jedna od najefikasnijih profilaktičkih mera u redukciji karijesa i zaštiti prvenstveno prvih stalnih molara od delovanja kariogenih agenasa je zalivanje fisura.

Zalivanje fisura je potpuno bezbolna tehnika i može poslužiti kao način za oslobađanje ili smanjenje straha kod pacijenata. Razumevanje dentalne anksioznosti od strane stomatologa je takođe neophodan uslov za uspostavljanje dobre komunikacije, kao i pravilnog pristupa pacijentu u svakodnevnoj praksi. 